\title{
Criminal Enforcement in the Area of Female Genital Mutilation in France, England and the Netherlands: A Comparative Law Perspective
}

\author{
Renée $\mathrm{Kool}^{1} \&$ Sohail Wahedi ${ }^{2}$ \\ ${ }^{1}$ Willem Pompe Institute for Criminal Law and Criminology/ Utrecht Centre for Accountability and Liability \\ Law (UCALL), Law Department, Utrecht University, The Netherlands \\ ${ }^{2}$ Law Department, Utrecht University, The Netherlands \\ Correspondence: Renée Kool, Willem Pompe Institute for Criminal Law and Criminology, Law Department, \\ Utrecht University, Boothstraat 6, 3512BW, Utrecht, The Netherlands. Tel: 31-30-253-7142. E-mail: \\ r.s.b.kool@uu.nl
}

Received: September 10, 2013 Accepted: October 28, 2013 Online Published: April 15, 2014

doi:10.5539/ilr.v3n1p1

URL: http://dx.doi.org/10.5539/ilr.v3n1p1

\begin{abstract}
The criminal justice system in Western countries is ever more frequently facing the question of how to deal with immigrants' cultural practices, such as honour killings, blood revenges and female circumcision, better known as 'Female Genital Mutilation', that are considered to be in violation of human rights. Especially practicing Female Genital Mutilation has been subjected to an intense debate in the last four decades. This debate culminated provisionally in the recently adopted resolution by the United Nations, which calls upon its member states to eliminate this practice. Despite such calls, the results of criminal enforcement in banning this practice diverge in many countries. This raise the question whether national views on citizenship and multiculturalism may offer an explanation for the divergent enforcement practices in the area of Female Genital Mutilation. This study pays in particular attention to the way France, England and the Netherlands have criminalised Female Genital Mutilation and whether the results of their legal approaches in banning this practice by using criminal law, can be declared from their particular notions of citizenship.
\end{abstract}

Keywords: Female Genital Mutilation, multiculturalism, citizenship, harmful cultural practices, human rights, criminal law

\section{Introduction}

The question as to how to deal with non-Western customs, including Female Genital Mutilation (hereafter: FGM), has confronted Western societies for some decades. After the initial struggle with the question, whether the perpetrator's cultural background should result in impunity or absence of guilt, it has become clear that by Western standards FGM is an unacceptable cultural practice. Human rights standards, interpreted in conformity with the classical liberal standards and values predominant in Western thinking with its focus on the damage principle, support this view. The keywords are 'harmful traditional practices', often supplemented by the statement that crimes contradictory to the 'views of civilised nations' are involved. (Note 1) This view is laid down in, among others, the recently adopted Convention of Lanzarote on combating (sexual) violence against women and girls. (Note 2)

The calls for a ban on FGM, based on the notion that it is a harmful and painful gendered practice to females, do not answer the more underlying question why female circumcision cannot be considered as a cultural exception in law, as is the case for some other unnecessary (controversial) cultural motivated surgical interventions, such as male circumcision and cosmetic surgery. (Note 3) The question arises furthermore whether Western countries are legitimised to qualify a non-Western cultural practice in terms of right or wrong, and if these countries are allowed to do so, is the only use of legal measure sufficient to eliminate this practice. (Note 4) In line with this the question arises furthermore why despite the consensus on the punishability of FGM, its enforcement diverges in Western Europe. (Note 5) In order to find out the reason for this, we studied the approach to FGM, more specifically the use of criminal law, in three countries: France, England, and the Netherlands. (Note 6) We compared not only the legal framework and the underlying policy, but also the underlying national views on 
citizenship. The reason being, that national views on citizenship may influence the way, in which Western European societies deal with multiculturalism. This might offer a (partial) explanation for the divergent enforcement practices in the area of FGM.

\section{Method}

This study focuses on the question whether the particular notions of citizenship, in the studied countries are of influence on criminal enforcement actions in countries studied. Our choice for these countries is based on our perception that outcomes in enforcement actions in banning FGM diverge strongly in these countries. We assume a relationship between the different outcomes in legal enforcement and the different notions of citizenship in the studied countries. Based on this intellectual goal and theoretical assumption, the conceptual framework of this study is constructed on works concerning notions on citizenship, different researches on the admissibility of 'harmful' cultural practices, as cultural exceptions in law, and the way substantive criminal law so far has reacted on such practices. The used concepts and theories to construct the conceptual framework declare our methodological choices. This qualitative legal research is based on comparative (legal) literature, case law and legislation concerning the theme that is studied.

We start with a short description of the phenomenon of FGM. This description is viewed from the human rights perspective that qualifies this practise as a 'harmful cultural practice', with the ensuing obligation of penalisation. This is followed by a description of the French, English, and Dutch legal approaches to FGM in the context of prevailing views on citizenship, and concluded by a comparison.

\section{Human Rights as a Basis for Enforcement}

The World Health Organisation (hereafter: WHO) describes FGM as follows: 'the partial or total removal of the external female genitalia, or any other injury to the female genitalia for non-medical reasons'. (Note 7) Worldwide between 130 and 150 million girls and women are established to be genitally mutilated in one way or another; approximately another three million girls are estimated to run the risk of being circumcised. FGM is practised mainly in parts of Northern Africa and Asia, but it is also reported to occur in Western Europe. It ranges from small operations (removal of the foreskin of the clitoris), (Note 8) to larger ones (the removal and sewing up of the labia majora or minora, sometimes in combination with the removal of the clitoris). As FGM as a rule is practised outside a medical context, health risks are usually involved; these will be more substantial in the event that genital mutilation takes place under primitive circumstances than within an urbanised Western setting.

There is no clear explanation for this age-old tradition. There are various reasons for practising FGM: sometimes it is based on religious beliefs (although religious texts do not support this), (Note 9) at other times it involves an initiation ritual within a group, from which the woman derives status. (Note 10). A critical interpretation hereof is reflected in human rights texts, assuming a gendered practice. This view, however, is not undisputed. (Note 11) The aforementioned interpretation clarifies matters, as it reveals the 'political' nature of international legislation (including human rights) and the underlying conceptualization of cultural practices. Such rules are the result of political negotiations, in which, when human rights are involved, the Western liberal discourse is predominant. In women-related matters, such as FGM, gender has been the dominant frame for some decades. Although this frame contains inconsistencies -e.g. cosmetical surgery catching on in the West (breast enlargement, corrections of the labia, etc.), is hardly ever problematised-, it strongly affects the evaluation of cultural practices that are qualified as gendered. (Note 12) From a pragmatical point of view the subsumption of FGM under human rights violations also fits in with the prevailing -Western- opinion that human rights are universal by nature. (Note 13)

The most far-reaching effect hereof may be found in the judgment that this is a cultural practice 'in contradiction with the views of civilised nations'. Within the sphere of influence of the European Convention on Human Rights (hereafter: ECHR), which is decisive for Europe, the applicability of this qualification has direct consequences for the requirements of criminal legality. On the basis of article 7 ECHR, the applicability of this qualification requires no previous, knowable penalisation any more: punishability is so obvious that no misunderstanding is possible on the basis of a moral intuition shared by all. In addition one often resorts to the argument of the universality of human rights. An easy appeal to this exceptional category, however, impairs the interest of both foreseeability and recognisability of punishability (requirement of legality) that is also protected as a human right. At the national level, however, one more or less automatically appeals to the applicability of this category, in the event that the punishability of cultural offences or related jurisdiction issues are concerned.

In the case of FGM, there may be good reasons for this. As a rule, major, possibly irreversible violations of a person's physical and mental integrity are involved, which are carried out without permission of the person concerned. (Note 14) But what if we are dealing with lighter forms of FGM? As a result of the 'indivisibility' of 
the gender frame and of the 'generous' use of the label 'contradiction with the views of civilised nations', these are also qualified as punishable behaviour, with the ensuing claim for both national and international jurisdiction.

Leaving aside the correctness of such a categorical penalisation, one cannot avoid the conclusion that the predominant human rights frame, which views FGM as a punishable practice, contains inconsistencies that raise questions as to the legitimacy of penalisation and criminal enforcement. Some sense of history also is in order here. For although one might presume otherwise in view of the present human rights course, FGM was not initially recognised as a human rights violation. (Note 15) After a slow start in the fifties, it even took until the mid-nineties for FGM to be put on the human rights agenda. As of then states have been under an obligation to develop legislation providing effective protection at state level. (Note 16)

At the European level this has been realised, as is shown by among others the Convention of Lanzarote and the case law of the European Court of Human Rights (hereafter: ECtHR). A restriction applies with regard to this last source: no case has yet been brought before the ECtHR, claiming the infringement of a Convention right on account of the lack of criminal law protection offered against FGM. Nevertheless, in its decisions on the application of migration law, the ECtHR has clearly indicated that member states are under an obligation to provide adequate and effective protection against FGM. (Note 17). Although in these cases FGM was deemed to violate article 3 ECHR (prohibition of torture and inhumane treatment), (Note 18) one may presume that FGM will also violate criminal law protection to be offered under other provisions of the Convention, such as the right to life (article 2 ECHR) or the right to physical and mental integrity (article 8 ECHR). With regard to the said serious violations the ECtHR as a rule deems it appropriate to resort to criminal law, resulting in the need for an adequate criminalisation and effective enforcement hereof. (Note 19) Both the association of female circumcision with mutilation and the starting point of criminalisation and effective enforcement suggest that the ECtHR will not be inclined to accept a cultural defence easily. This is in line with other human rights conventions that explicitly exclude an appeal to tradition in order to justify violent practices against girls and women. (Note 20)

\section{Intermezzo: Notions of Citizenship}

Although magnification should be avoided and factual (im)possibilities set the political agenda, a comparative analysis of the criminal law approach of FGM calls for a closer look at society's views on multiculturalism, which in their turn are to be related to views on citizenship. FGM is a cultural offence and this colours the issue of the prosecutorial discretion. Moreover, in case of prosecution a cultural defence may be advanced. The answers of the criminal justice system to both the question of prosecutorial discretion and the question of assessment of the cultural defence are (also) determined by views in society on the need for immigrants to assimilate, and the extent to which they are allowed to hold and to practice cultural minority views. Although the (mostly) major and irreversible character of FGM limits the 'workspace' of criminal law, society's views on multiculturalism also are relevant here.

We use three models of citizenship derived from literature: the republican, the ethnocultural, and the multicultural model. (Note 21) The model a country belongs to depends on factors such as the degree to which newcomers are eligible to obtain citizenship of the host country, and the way in which a country recognises diversity.

Anticipating on the 'country analyses', it can be said that France fits in with the republican model. It is more complicated to decide, which models apply to England and to the Netherlands. In the past, and to a certain degree this still is true for England, both countries applied a multicultural model. (Note 22) This model embraces diversity and accepts differences. However, under the influence of a growing globalisation and a global fear of Muslim terrorism, in recent years, views on citizenship have emerged that fit in better with an ethnocultural model. Like the republican model, this model focuses on a culturally homogeneous society, resulting in less scope for diversity.

Bearing in mind the relativity of these models, we have made 'country analyses'. As France is the only European country that actively enforces in the area of FGM -or so it appears-, we have taken the liberty of elaborating on this case.

\section{France}

In the past decades France, like other Western European countries, has had a pressing need for labour immigrants. (Note 23) Until the early seventies of the previous century it conducted a 'laissez-faire' immigration policy, which, as a result of the subsequent economic crisis, made way for an 'ethnocentric assimilation policy'. (Note 24) The French preference for a centralistic approach and for universalism resulted in a more restrictive 
assimilation policy aimed at maintaining French unity, within which cultural differences were to be minimized and cultural assimilation was expected of the newcomers. (Note 25) The emphasis shifted to restricting immigration and to 'integration à la française'. (Note 26) This assimilation policy had its impact in various areas, including the approach of FGM.

This new assimilation policy did not focus on FGM from the onset. On the contrary, due to the belief that the newcomers were prepared to live according to the French values and to distance themselves from their original cultural background, a blind spot for cultural inequalities existed for quite some time, especially with regard to the position of women and children. Those data were ignored and therefore not registered, as a result of which they remained invisible, at least officially. (Note 27). The idea that an official care policy had to be developed in order to prevent 'social, ethnical or religious particularism' (i.e. FGM) within the minority group, with the ensuing violence against women and children, was recognized insufficiently for a long time. (Note 28)

At the time the death of a baby, baby Bobo, opened up the issue. The little girl died in 1982 as a result of the serious wounds inflicted upon her during her circumcision. (Note 29) The tone of the resulting major media coverage indicated that the prevention policy pursued so far would no longer suffice. It became obvious that baby Bobo was not the only victim: care providers working in infant and youth health care (Protection Maternelle et Infantile, hereafter: PMI) reported to have been confronted before with (the consequences of) FGM. In the arrondissements in which many immigrants had settled (especially around Paris), these circles insisted that enforcement be tightened up.

The fact that PMI played a prominent role in opening up the issue of FGM has to do with the fact that the parents of children born in France are obliged to have their children undergo medical examinations until the age of six, irrespective of their residency status. An examination of the genitals is part hereof. In conformity with the French views on obedience owed the authorities, this obligation as a rule is not questioned. (Note 30) This also applies to immigrants. For them the fact that PMI offers freely available health care, something they otherwise would not be able to afford, also plays a role.

In addition, a PMI doctor, discovering a genital mutilation during a medical check, is under an obligation to report this to the procureur de la République, despite his/her duty of confidentiality. (Note 31) Despite the fact that not all PMI doctors are willing to report, a larger degree of cooperation between doctors and criminal authorities exists than elsewhere. (Note 32) An important fact at the time was that most reports coming in after baby Bobo's death led to two identifiable cutters. As a result, more cases were discovered and criminal prosecutions were started. (Note 33) This complex of factors has contributed in large part to the success status awarded to France internationally.

There is more, however, as the organisation of French criminal investigation and more specifically the prominent presence of the investigating judge, also plays a role. When the police are on the track of a cutter, they call in an investigating judge, who has wide, independent investigative powers. In combination with PMI's readiness to provide information in connection with the report, building a criminal case was relatively easy. (Note 34) The information provided by the PMI doctor consists of: the parents' statements made during conversations between them and the PMI doctor, the doctor's medical statement, and the victim's medical file, holding information on the latest status of the genitals. (Note 35) Here again, parents responding to an invitation for a conversation and doctors collecting such information is more 'self-evident' in the French setting than elsewhere.

But a note should also be made. Reports mainly originated from PMI doctors in the Paris region. This region has a high concentration of immigrant groups practising FGM and one is often confronted with the medical consequences of genital mutilation. This does not alter the fact that there are concentrations of these groups in other parts of France as well; however, activities by the judicial authorities are at a lower level there. (Note 36) What's more, Nijboer et al. conclude that, as a rule, the French police are not actively involved in investigating FGM, with the exception of the cutter cases. (Note 37)

The last (cultural) factor that is important for a correct understanding of the French 'success' is the fact that interest groups are entitled to join as a party during a preliminary judicial investigation. (Note 38) These NGOs (Note 39) at the time advocated settling criminal cases regarding FGM at the highest criminal level, i.e. the Cours d'Assises, instead of at the level of the single judge as chosen in first instance. The underlying idea being that the fight against FGM should also have the character of a public warning. A jury trial before the Court d'Assises, drawing a lot of attention, promoted public visibility of the issue. (Note 40)

All in all, some forty criminal cases have been settled in France thus far, most of these ending in a conviction. (Note 41) Frequently, appeals were made to the cultural background of the accused(s), in order to justify the genital mutilation or to exclude one's own punishability. In a number of cases experts established circumstances 
beyond the accused's control, but this defence has never been admitted. (Note 42) In other cases the accused invoked error of law, arguing that as an immigrant, they had not been aware of the fact that FGM is punishable in France. Nijboer et al. are of the opinion that these defences were meant to influence the nature and scope of the sentence, not to effect an acquittal or an exemption from punishment. This effect appears to have been realised, i.e. with regard to the parents. The cultural background of the accused and the wish not to disrupt family life are stated as reasons for relatively light sentences. (Note 43) By contrast, the cutters were often sentenced to severe and unconditional imprisonment, especially if they had been involved in a series of circumcisions.

This French 'success' later attracted the attention of other countries, especially of the Netherlands. (Note 44) Nevertheless Nijboer et al. argue that things should be put into perspective, as most French criminal cases resulted directly from the arrest of a cutter. (Note 45) There have been very few reports on any other basis, with the exception of some active PMI circles, and there is no integrated official approach. (Note 46) The nationwide familiarity with the punishability of FGM that was generated by the criminal cases has not opened up the issue any further, nor intensified the combat thereof.

Notwithstanding the aforementioned qualifications, the question arises whether, and to what extent, the characteristically French republican views on immigration and assimilation have contributed to the French 'success'. This does appear to be the case, albeit with the usual provisos. It was pointed out that in the French setting the acceptance of authority, as implied in the hierarchical relations between citizen and government, is more self-evident. The question, whether parents are under an obligation to participate in a routine examination of the genitals by a doctor and to make a relevant statement is not being raised, it is simply accepted. (Note 47) The readiness of the various authorities to cooperate, especially the readiness in specific regional medical circles to report their findings directly to the criminal authorities, also testifies to a 'centralistic' attitude that is lacking elsewhere. The fact that, due also to the NGOs' involvement, the message was phrased in terms of promoting the equality of the sexes and protecting human rights furthermore promotes public and political support. (Note 48)

This attitude also explains why one did not opt for a specific penal provision. The women's movement was in favour hereof, but it was rejected in conformity with the French republican spirit to realise one shared identity. The introduction of a specific penal provision would differentiate between citizens and thus might lead to discrimination and stigmatisation of minority groups. (Note 49) The French legislator continues to adhere to this methodology. In order to meet the explicit demand for criminalisation contained in article 38 of the Lanzarote Convention, a legislative proposal was nevertheless drafted with the aim of supplementing the general provision on abuse (article 222-9 Code Penal) by the element 'mutilation génital feminine'. Another proposal was made that explicitly criminalises the attempt to and/or the furtherance of FGM. This proposal is still pending. (Note 50) By contrast, an agreement was reached on the need to extend extraterritorial jurisdiction, in view of FGM practised on French citizens abroad. The original connecting factor, requiring either the suspect or the victim to be a French national at the time of the offence, was relinquished in 2006 and one now also has jurisdiction in case of an underage victim with a permanent resident status. (Note 51)

\section{England}

The English approach to FGM must be viewed against the background of the 'compounded character' of the British Empire and its long colonial history. For many years, English society underwent a large-scale and prolonged immigration, which (has) shaped English views on citizenship. Some say that this colonial past has left the British, including the English, with a multicultural gen, discerning them from other Europeans. (Note 52)

This self-image is illustrated by a statement of former Prime Minister Blair, in 2000 given in reaction to the Parekh-report: (Note 53)

“This nation has been formed by a particularly rich complex of experiences: successive waves of invasion and immigration and trading partnerships, a potent mix of cultures and traditions which have flowed together to make us what we are today. Blood alone does not define our national identity. How can we separate out the Celtic, the Roman, the Saxon, the Norman, the Huguenot, the Jewish, the Asian and the Caribbean and all the other nations that have come and settled here? Why should we want to? It is precisely this rich mix that has made all of us what we are today."

Fortier, however, points to the polarising tone of the Parekh report, and to the very critical attitude adopted herein with regard to the designation 'the English cultural identity'. (Note 54) Others have also questioned this multicultural identity that is publicly adhered to by politicians. (Note 55) They point to underlying racism and animosity towards immigrants, inspired by the fear of Muslim terrorism. (Note 56) They conclude that the past years have seen a shift in political thinking towards assimilation and integration. 
Nevertheless, the English views on citizenship still exemplify the multicultural model. Although the former policy of 'equal opportunity, coupled with cultural diversity' (Note 57) has become a bit worn, it has not been abandoned completely yet. The political feelings of guilt as regards the 'racist' (colonial authors') past' are too deeply rooted according to Mirza. (Note 58) This is reflected in the political influence of the multicultural NGOs on English policy with regard to FGM. More than elsewhere, the English authorities take into account the opinions of (locally) organised minority groups and consult these, when outlining policies on multicultural issues. (Note 59) This policy characteristic also applies to the area of national health care, an important area in the fight against FGM. (Note 60) However, the involvement of these NGOs also has a downside: when issues of criminalisation and the criminal enforcement of cultural offences, such as FGM, are concerned, this quarter is quick in raising suspicions of racism against government policy. (Note 61) At the same time there has been a growing awareness in England that violations of human rights are to be prevented. (Note 62)

On balance, England appears to be in a transitional phase with regard to the approach to FGM (and other cultural offences). On the one hand, one still aims for a policy that enjoys wide support and does not clearly pursue a homogeneous national identity. However, it should be noted that societal unrest regarding the consequences of globalisation, together with the fact that the fight against FGM has not been successful in the past years, has resulted in a stronger emphasis on repression. This indicates a shift towards an ethnocultural model. (Note 63)

The question as to why the English authorities thus far have not managed to prevent FGM and/or to fight it through criminal law is not an easy one to answer. With regard to prevention, one may ask whether this has not actually been effected, we simply don't know. What we do know is that FGM occurs on a large scale in England. For lack of adequate registration we can only guess at the scope hereof; reasoned estimates come up with 20,000 high-risk cases. (Note 64) Later research by the Health Department however mentions 80,000 high-risk cases, i.e. over a quarter of all girls originating from immigrant groups under the age of fifteen. (Note 65) The majority of these girls is in the ages between seven and ten and originates from Kenya and Somalia.

The legislator cannot be blamed for inadequate enforcement. On the contrary, in the European context England is leading with regard to legislation. Already in 1985 the Prohibition of Female Circumcision Act was adopted, with the main purpose of promoting awareness. In addition to a specific penal provision, this act allows for genital circumcision on medical grounds. Despite its lack of clarity on the precise conditions under which this is permitted, it is clear that the woman's conviction of the rightness of the circumcision as prescribed by tradition does not constitute a justification. (Note 66) It is also noteworthy that the penal provision covers the genital mutilation of adult women at their own request. Moreover, the 1985 Act was replaced by the Female Genital Mutilation Act 2003; under this act, a substantially increased maximum sentence (from five to fourteen years of imprisonment) applies and extraterritorial jurisdiction is extended, so that genital mutilations practised abroad by and on English citizens can also be prosecuted. (Note 67)

In addition, the Crown Prosecution Service (hereafter: CPS) has drafted instructions on fighting FGM adequately (FGM Guidance). (Note 68) These instructions are part of the broader policy of the CPS on fighting violence against women (Violence Against Women Strategy and FGM), which policy in turn is incorporated in the coordinating policy on fighting violence against women. (Note 69) It is also noteworthy that anyone having a suspicion of child abuse, including FGM, is under an obligation to report this to the local social services or to the police (Children Act 1989, section 47). (Note 70) This applies, despite possible professional confidential duties. (Note 71)

The English government, pressured by growing criticism of the observed enforcement deficit, has announced its intention to intensify combating FGM. (Note 72) Slowly but surely the government is pulling the (criminal law) strings. A matter of permanent concern is increasing the willingness to report. An attempt is made to open up the issue through a community based multi-agency approach. Besides, local authorities are entitled to take preventive measures if this is necessary to protect the child's health (custodial placement, request of ban to leave the country). The Crown Prosecution Service recently stated that it intends to start implementing these child protection measures in fighting FGM. Thus far this policy has not led to any concrete acts of prosecution. (Note 73)

At the end of this description of the English case the question arises, whether and to what extent the English views on citizenship influence (have influenced) the combating of FGM. Although there is no clear answer to this, it is possible to discern an 'English signature', subject to the necessary provisos. Unlike the French ideology, there is no 'centralistic' approach based on a homogeneous cultural identity. On the contrary, in the English setting one traditionally feels very strongly about every person's claim to their own cultural identity. Beneath the surface of this multicultural model, however, a trace of ethnocentrism has been spreading, inspired by an 
unspoken but nevertheless strongly felt superiority of the 'real' English identity. This trace has been picked up by minority groups and has led to accusations of racism, which in turn interferes with the identification of FGM as a (cultural) offence.

\section{The Netherlands}

We will finally discuss the Dutch case. In Western Europe the Netherlands are by no way among the leaders with regard to the criminal law approach to FGM. On the contrary, the Netherlands started combating FGM quite late, i.e. only in 1993. (Note 74) Around that time the multicultural model of citizenship ('integrating while preserving one's own culture') that had prevailed in the Netherlands in the seventies was already starting to shift. (Note 75) The impact of the surge of labour immigrants that had started in the sixties made itself felt at the end of the twentieth century and resulted in a political swing; the new slogan became 'adjusting through embracing the Dutch identity'. (Note 76) As of 2004 parliamentary debates and government circles showed an official dissociation from 'multiculturalism as a normative ideal'. (Note 77) As of then an ethnocultural model of citizenship became popular that was characterised by a 'thick', homogeneously presented, Dutch identity. (Note 78) Its roots may be found in the former 'pillarisation' (i.e. the compartmentalisation of Dutch society along traditional religious and socio-political barriers), entailing the policy of sovereignty within one's own circle ('pillar'). Although this policy was abandoned in the middle of the past century, in the wake of the 'depillarisation', the inherent typical development of identities along the lines of group building stayed intact beneath the surface. (Note 79)

In this political climate a firm stand was made against FGM from the start. Its punishability was stressed, and it was labelled as an 'imported offence'. (Note 80) The seriousness of the consequences led to its qualification as child abuse, an issue for which criminal law enforcement was (also) deemed appropriate. In conformity with the system of Dutch criminal law, one chose to apply the common criminal provisions (article $300 \mathrm{ff}$ of the Dutch Criminal Code: Wetboek van Strafrecht). (Note 81) Nonetheless, these were not enforced in an active way initially. One did not aspire to this; due to the sensitivity of the issue, criminal investigation was considered undesirable. (Note 82)

FGM now falls under the heading of domestic violence, which is one of the spearheads of present criminal law policy. (Note 83) The view that criminal law intervention may be appropriate in cases of FGM is undisputed in present policy. What is more, the Dutch government at present also claims jurisdiction with regard to genital mutilations of nationals or residents, which were practised elsewhere. To this purpose it extended its extraterritorial jurisdiction in 2006 and 2013. (Note 84) The provisions on the prescription of the right to prosecute were also extended. Under Dutch law the prosecution term for a victim of FGM only commences on her coming of age (18 years); the underlying idea being, that the victim needs time to break away from the family ties, in order to be able to consider whether she wishes to report her parents and/or other family members to the police on account of genital mutilation.

Despite the fact that criminal law currently is an integral part of the approach to FGM, preference is still given to prevention and the rendering of assistance. Support for criminal law enforcement has increased lately, but the medical and youth services still adopt a reticent attitude. They are often not prepared to report suspicions and observations on FGM to the criminal authorities. This attitude has been respected by the government thus far; however, a legal obligation for medical services to report suspicions to one of the Child Abuse Reporting Centres $(A M K s)$ was introduced recently. (Note 85$)$ The procedure will consist of a gradual process of internal consultation and consolidation of suspicions of child abuse (including FGM), after which, only in last instance and on condition of a sufficient indication, a report is to be made to the criminal authorities. (Note 86) It is doubtful whether this will open up the issue to include criminal law. All the more so, as since the introduction of the Social Support Act in 2010, policy responsibility for the prevention of FGM lies on the local level. As a rule, this local level does not opt for criminal intervention, but focuses on opening up the issue via the communities involved through the interference of key figures. It is presumed that the minority groups involved should also carry responsibility for the problems within these groups, i.e. from a Dutch perspective. (Note 87)

The question as to whether the Dutch approach has proven fruitful and what fruits it has borne is not an easy one to answer. In terms of the number of criminal cases the result is meagre: thus far only one case was submitted to the criminal court, which ended in an acquittal for lack of evidence. (Note 88) Moreover, this case was only opened up to the criminal authorities following a report by the (Dutch) mother. (Note 89) Politicians, however, insist that combating FGM through criminal law should be intensified. (Note 90) At the same time one is aware of the repercussions of a criminal intervention; insisting on tightening criminal repression therefore mainly seems to serve the purpose of demonstrating to the public that FGM is absolutely forbidden in the Netherlands, 
in the hope of deterring potential perpetrators. The extension of extraterritorial jurisdiction, which was introduced a while ago and extended recently, also fits into this context.

This is in line with a general tightening of the criminal regime with regard to cultural offences that is currently visible in the Netherlands. (Note 91) It is obvious that the Dutch government wishes to draw the line with regard to the impunity of cultural practices more clearly. In doing so, the Dutch government is convinced of being in the right, both from a human rights and from a cultural angle. (Note 92) Objections against extending penalisations and, in the wake thereof, extraterritorial jurisdiction were invariably rejected with the argument that the disputed actions violate 'the views of civilised nations'. These, in the prevailing policy view, render it foreseeable for everyone that both FGM and other cultural offences constituting violations of human rights are punishable according to Western views. The Dutch approach to FGM thus shows ethnocultural features. (Note 93)

\section{Comparison and Conclusion}

The French, the English and the Dutch society are all in their own manner clearly struggling with the impact of globalisation and the resulting influx of non-traditional cultural practices. Their approaches differ due to (legal) cultural differences and underlying views on citizenship, but these seem to be differences of degree. The conviction that, measured by Western views, FGM is punishable and should be combated is beyond dispute in all three countries. There also is more or less agreement on the approach: the focus is on prevention and assistance, with criminal law functioning as the tailpiece.

It is this last issue, the use of criminal law, or to be more precise, the overlap of assistance and criminal law, where the biggest differences occur. The readiness of national governments, but even more so, of practitioners to actually resort to criminal law diverges. The existence of a specific criminal provision is not decisive in this respect, as is shown by the French practice. Not the law, but practice decides, whether there is support for actual criminal law intervention. And this practice, as it turns out, is determined by the degree of tolerance toward cultural practices that is implied in national ideas on citizenship.

Although it is not possible to draw hard conclusions, in view of the limitations of an analysis presented in an article, the French and Dutch societies seem to take a 'harder' stand on FGM than the English society. The message that newcomers are expected to adjust to the standards of the new motherland and must assimilate can be heard clearly, both in France and in the Netherlands. Such a centralist approach fits into the relatively simple political administrative structure of the Netherlands, as compared to France and England. The fact that the same message applies in France, despite the more complex political administrative structure, provides an extra layer to the felt homogeneity of the French identity. The contrary, however, applies to England: the same complex political administrative structure tends to lead to the recognition of various cultural identities, of which the English identity is then felt to be 'superior'. All these factors influence the approach to FGM in these countries.

But there also are similarities. Like all Western European countries, all three countries are bound hand and foot, but also with their heart and soul, to human rights. States are therefore expected to provide adequate protection against gendered cultural practices that are considered to be harmful. This justifies the use of criminal law, in the course of which the human rights' claim to universality leads to an extension of jurisdiction. At the practical level, however, the actual role of criminal law appears to be defined by the complexity of the issue of FGM and the related multicultural aspects, with the need of weighing opposite interests. It may come as no surprise, that to date not one of these countries - France included - has been able to fight FGM adequately. The search for the 'correct approach' will continue for a while, both at home and abroad.

\section{References}

Abdullahi, A. N. (2000). Islam and Human Rights: Beyond the Universality Debate. In American Society of International Law, Proceedings of the 94th Annual Meeting (pp. 94-101).

American Psychological Association. (1972). Ethical standards of psychologists. Washington, DC: American Psychological Association.

APPG. (2000). Parliamentary Hearings on FGM report. London: APPG. See also HM Government. (2013). Call to an end Violence against Women and Girls, Action Plan. London: HM Government.

Berkovitch, N., \& Bradley, K. (1999). The globalization of women's status: Consensus/Dissensus in the World Polity. Sociological Perspectives, 42(3), 481-498.

Black, J. A., \& Debelle, G. D. (1995). Female Genital Mutilation in Britain. BJM, 310, 1590-1592.

Brems, E. (1997). Enemies or allies? Feminism and Cultural Relativism as Dissident Voices in Human Rights Discourse. Human Rights Quarterly, 19(1), 136-164. 
Council of the European Union. (2011, April 7). Convention on preventing and combating violence against women and domestic violence. Retrieved from https://wcd.coe.int/ViewDoc.jsp?id=1772191

Council of the European Union. (2011, April 7). Convention on preventing and combating violence against women and domestic violence. Retrieved from https://wcd.coe.int/ViewDoc.jsp?id=1772191

Dorkenoo, E., Morison, L., \& Macfarlane, A. (2007). A Statistical Study to Estimate the Prevalence of Female Genital Mutilation in England and Wales. London: Forward.

Dustin, M. (2010). Female Genital Mutilation/Cutting in the UK. European Journal of Women's Studies, 17(7), $1-31$.

Fortier, A. M. (2000). Multiculturality and the new face of Britain. Lancaster: Department of Sociology. Retrieved from www.lancs.ac.uk/fass/sociology/papers/fortier-multicultuturalism.pdf.

Fortier, A. M. (2005). Pride politics and multiculturalist citizenship. Ethnic and Racial Studies, 28(3), 559-578.

Ghorashi, H. (2006). Paradoxen van culturele erkenning [Paradoxes of cultural recognition]. Tijdschrift voor Genderstudies [Periodical for Gender Studies], 9(4), 42-54.

Guiné, A., \& Moreno Fuentes, F. J. (2007). Engendering Redistribution, Recognition, and Representation: The case of Female Genital Mutilation (FGM) in the United Kingdom and France. Politics Society, 35(3), 477-519.

Gunning, I. R. (1992). Arrogant Perception. World Travelling and Multicultural Feminism: The Case of Female Genital Surgeries. Columbia Human Rights Law Review, 23(2), 189-248.

't Hart, A. C. (2000). Hier gelden wetten! [Here the laws apply!]. Deventer: Gouda Quint.

Henrion, R. (2003). Mutilation génitals feminine, marriages forcés et grossesses précoces. Bulletin de l'Académie nationale de médecine, 187(6), 1051-1066.

HM Government. (2012). A Statement Opposing Female Genital Mutilation. London: HM Government.

Home Office. (2011). Female Genital Mutilation Multi Agency Practice Guidelines. London: HM Government.

Home Office. (2013). Domestic Violence. London: Home Office, which contains a new definition of violence against women, including female genital mutilation. This definition is effective as of March 2013; Retrieved from www.homeoffice.gov.uk/crime/violence-against-women-girls/domestic-violence.

Jugé, T. S., \& Perez, M. P. (2006). The modern colonial politics of citizenship and whiteness in France. Social Identities, 3, 187-212.

Kalev, H. D. (2004). Cultural Rights or Human Rights: The Case of Female Genital Mutilation. Sex Roles, $51(5 / 6), 339-348$.

Kool, R. S. B. (2010). The Dutch approach to female genital mutilation: The time for change has come. Utrecht Law Review, 1, 51-71.

Kool, R. S. B. (2012). Drassige gronden voor strafbaarstelling [Sloppy grounds for penalisation]. Delikt en Delinkwent, 1, 21-35.

Kool, R. S. B., Beijer, A., Eelman, J., \& Knoops, G. (2005). Vrouwelijke genitale verminking in juridisch perspectief [Female genital mutilation in a legal perspective]. Zoetermeer: Raad voor de Volksgezondheid [National Advisory Council for Public Health].

Koopmans, R., Statham, P., Giugni, M., \& Passy, F. (2005). Contested Citizenship. The Contentious Politics of Immigration and Ethnic Relations in Germany, Britain, France, the Netherlands and Switzerland. Minneapolis: University of Minnesota Press.

Lewis, H. (1995). Between Irua and "Female Genital Mutilation": Feminist Human Rights Discourse and the Cultural Divide. Harvard Human Rights Journal, 8, 1-55.

Leye, E., Deblonde, J., García-Añón, J., Johnsdotter, S., Kwateng-Kluvitse, A., Weil-Curiel, L., \& Temmerman, M. (2007). An analysis of the implementation of laws with regard to female genital mutilation in Europe. Crime, Law and Social Change, 47, 1-31.

McCormick, D. (2005). Multiculturalism and its Discontents. Human Rights Law Review, 1, 27-56.

Mirza, H. S. (2012). Multiculturalism and the gender gap: The visibility and invisibility of Muslim women in Britain. In W. I. U. Ahmad, \& Z. Sardar (Eds.), Muslims in Britain. Making social and political space (pp. 120-139). Abingdon: Routledge. 
Nijboer, J. F., Van der Aa, N. M. D., \& Buruma, T. M. D. (2010). Strafrechtelijke opsporing en vervolging van vrouwelijke genitale verminking. De Franse praktijk [Criminal law investigation and prosecution of female genital mutilation. The French practice]. The Hague: Boom, at 113.

Poulter, S. (1986). Ethnic Minority Customs, English Law and Human Rights. International and Comparative Law Quarterly, 36(3), 589-615.

Raad voor de Volksgezondheid [Council for Public Health and Care]. (2005). Bestrijding vrouwelijke genitale verminking. Beleidsadvies [The fight against female genital mutilation. Policy advice]. Zoetermeer: Raad voor de Volksgezondheid.

Runnymede Trust. (2000). The Future of Multi-ethnic Britain (Parekh report). London: Runnymede.

Sales, R. (2012). Britain and Britishness: Place, belonging and exclusion. In W. I. U. Ahmad, \& Z. Sardar (Eds.), Muslims in Britain. Making social and political space (pp. 33-53). Abingdon: Routledge.

Shweder, R. A. (2002). What about Female Genital Mutilation? And Why Understanding Culture Matters in The First Place. In R. A. Shweder, M. Minow, \& H. Rose Markus (Eds.), Engaging Cultural Differences: The Multicultural Challenge in Liberal Democracies (pp. 2016-251). New York: Russell Sage Foundation.

Smith, C. (2011). Who defines "Mutilation"? Challenging Imperialism in the Discourse of Female Genital Cutting. Feminist Formations, 1, 25-46.

Van Boven, T., \& Puig, S. (2005). Domestic Violence against women and torture. In I. Westendorp, \& R. Wolleswinkel (Eds.), Violence in the Domestic Sphere (pp. 59-71). Antwerpen/Oxford: Intersentia.

Van den Brink M., \& Tigchelaar, J. (2012). Shaping genitals, shaping perceptions: A frame analysis of male and female circumcision. Netherlands Human Rights Quarterly, 30(4), 417-445.

Van Meeteren, M. (2005). Discoursen van integratie. De omslag in het politieke debat over integratie in Nederland [Discourses of integration. The turnaround in the political debate on integration in the Netherlands], Master thesis Sociology, Rotterdam: EUR.

Wahedi, S. (2012). De wederrechtelijkheid van jongensbesnijdenis: Een ethische uitdaging voor het strafrecht? [The punishability of male circumcision: an ethical challenge for criminal law?]. Nederlands Juristenblad, 44/45, 3097-3105.

Wheeler, P. (2004). Eliminating FGM: The Role of the Law. The International Journal of Children's Rights, 11, 257-271.

Wihtol de Wenden, C. (2003). Assimilation and struggle of Maghrebi Immigration and French political culture. Culture \& Society, 2, 69-74.

Winter, B. (1994). Women, the Law and Cultural Relativism in France: The Case of Excision. Journal of Women in Culture and Society, 19(4), 939-973.

World Health Organisation. (2011). An update on WHO's work on Female Genital Mutilation (FGM). Retrieved from http://whqlibdoc.who.int/hq/2011/WHO_RHR_11.18_eng.pdf

WRR. (2001). Immigratie- en integratieregimes in vier Europese landen [Immigration and integration regimes in four European countries]. The Hague: WRR.

WRR. (2006). Identificatie met Nederland [Identification with the Netherlands]. Amsterdam: Amsterdam University Press.

Young, J. (1999). The Exclusive Society. London: Sage.

\section{Case Law}

ECtHR 20 September 2011, appl.no. 8969/10, (Omeredo/Austria).

ECtHR 17 May 2011, appl.no. 43408/08 (Izevbekhai C.S./Ireland).

ECtHR 8 March 2007, appl.no. 23944/05 (Collins \& Akaziebie/ Sweden).

Hof [Court of Appeal] Amsterdam 23 December 2012, LJN BO8531

Rb [District Court] Haarlem 11 September 2009, LJN BJ7447

\section{Parliamentary Papers}

Tweede Kamer der Staten-Generaal. Parliamentary Papers II 2011/12, 28 345, no. 117.

Tweede Kamer der Staten-Generaal. Parliamentary Papers II 2003/04, 29 200, XVI, 231, p. 7. 
Tweede Kamer der Staten-Generaal. Appendix Parliamentary Papers 1990/91, no. 1125, p. 2.

Assemblée Nationale. (24 June 2010). doc. no. 2658

Assemblée Nationale. (13 November 2012). doc. no. 368.

\section{Dutch Government Gazette}

Stcrt. 2013, 8838.

Stbl. 2013, 95.

Stcrt. 2010, 19123.

Stbl. 2006, 11.

\section{Notes}

Note 1. Critical hereof: Dustin, M. (2010), especially at 19 where she criticises the qualification of female genital mutilation as a harmful cultural practice as a product of the 'external messiah syndrome', practised in Western thinking. See also: Van den Brink M., \& Tigchelaar, J. (2012).. By qualifying female genital mutilation as a 'bad tradition', the right to culture is absorbed as it were by the -from a Western perspective- 'superior' right to physical and psychological integrity.

Note 2. Council of the European Union. (2011, April 7). Convention on preventing and combating violence against women and domestic violence. Retrieved from https://wcd.coe.int/ViewDoc.jsp?id=1772191

Note 3. Comp. Wahedi, S. (2012).

Note 4. Dustin refers to Gunning, I. R. (1992), see Dustin, M. (2010).

Note 5. Leye, E., et al. (2007).

Note 6. The term England is used to refer to the policy pursued in England \& Wales, countries of the United Kingdom. Although to outsiders this distinction might seem a bit contrived, it is commonplace in British/English literature, especially in relation to societal views on the punishability of cultural practices.

Note 7. World Health Organisation. (2011). An update on WHO's work on Female Genital Mutilation (FGM). Retrieved from http://whqlibdoc.who.int/hq/2011/WHO_RHR_11.18_eng.pdf

Note 8 . This type is sometimes compared to male circumcision. On the differences between male and female circumcision from the human rights perspective, see: Van den Brink, M., \& Tigchelaar, J. (2012).

Note 9. Kalev, H. D. (2004); Leye, E., et al. (2007), at 2.

Note 10. Berkovitch, N., \& Bradley, K. (1999), at 488.

Note 11. On the 'double standard' in the definition of female genital mutilation as a harmful practice: Shweder, R. A. (2002). See also Dustin, M. (2010).

Note 12. Lewis, H. (1995); Smith, C. (2011); Dustin, M. (2010), at 10; Van den Brink, M. \& Tigchelaar, J. (2012), pp. 439-441. See also: Brems, who points out that the increased thinking in terms of women's rights and the related interest for gender has led to a fundamental subordination of the right to culture; Brems, E. (1997).

Note 13. Abdullahi, A. N. (2000), at 96; Van den Brink, M. \& Tigchelaar, J. (2012).

Note 14. This is not applicable, however, to genital mutilations that are performed on adult women at their own request. Even those were sometimes made punishable explicitly, e.g. article 5 (1) (3) and (5a) of the Belgian Criminal Code and article 5 of the English Female Genital Mutilation Act 2003.

Note 15. Berkovitch, N., \& Bradley, K. (1999), at 489; Kalev, D., (2004), at 340; WHO (2011), at 1; Van den Brink, M. \& Tigchelaar, J. (2012), at 440, they point to the human rights prioritization of the right on culture at the time.

Note 16. Wheeler, P. (2004).

Note 17. This relates to migration law cases: ECtHR 20 September 2011, appl.no. 8969/10, (Omeredo/Austria); ECtHR 17 May 2011, appl.no. 43408/08 (Izevbekhai C.S./ Ireland); ECtHR 8 March 2007, appl.no. 23944/05 (Collins \& Akaziebie/Sweden).

Note 18. Van Boven, T., \& Puig, S. (2005).

Note 19. For a discussion of this case law as applied to female genital mutilation: Kool, R. S. B. (2010). 
Note 20. Among others the Council of the European Union. (2011, April 7). Convention on preventing and combating violence against women and domestic violence. Article 12 (5). Retrieved from https://wcd.coe.int/ViewDoc.jsp?id=1772191

Note 21. McCormick, D. (2005); WRR. (2006).

Note 22. Koopmans, R., et al. (2005).

Note 23. WRR. (2001), at 83.

Note 24. Guiné, A., \& Moreno Fuentes, F. J. (2007), at 490.

Note 25. WRR. (2001), at 93.

Note 26. Jugé, T. S., \& Perez, M. P. (2006), at 199; Wihtol de Wenden, C. (2003); Winter, B. (1994).

Note 27. No accurate figures on the extent of female genital mutilation in France are available. It is estimated that between 42.000 and 61.000 women were genitally mutilated in France. Some four thousand more girls run the risk of being genitally mutilated. See Leye, E., et al. (2006), at 365.

Note 28. Guiné, A., \& Moreno Fuentes, F. J. (2007), at 491.

Note 29. Winter, B. (1994), at 944; Kool, R. S. B., et al. (2005).

Note 30. Nijboer, J. F., et al. (2010), at 113.

Note 31. Articles 4 and 44 of the Code de Déontologie Médicale. Breaching the duty of confidentiality, apart from the exceptions following from article 226-14 Code Penal, constitutes a crime, but here an exception applies. Many care workers are not acquainted with the duty to report. As a consequence hereof directives were drafted for the PMI doctors. It appears from the case law that immediate action is only required if the danger to the patient's health is of an imminent and constant nature. See Henrion, R. (2003).

Note 32. Nijboer, J. F., et al. (2010), at 183-184.

Note 33. This concerns the cases Keita (1991) and Greou (1994). For a description of these -and other- French legal cases: Nijboer, J. F., et al. (2010), at Appendix 5.

Note 34. According to Nijboer et al. in each of the cases tried indications against the cutter as well as (one of) the parent(s) were present: Nijboer, J. F., et al. (2010), at 185.

Note 35. The victim is examined by a forensic gynaecologist at the request of the procureur de la République and with the permission of the possibly appointed temporary guardian. This is done to prevent the advance in court, on the basis of a countercheck report, of the defence that the girl has not been genitally mutilated: Nijboer, J. F., et al. (2010), at $124 \mathrm{ff}$.

Note 36. Nijboer, J. F., et al. (2010), at 18.

Note 37 Nijboer, J. F., et al. (2010), at 167: where they point out that 'the reactive character of the French criminal approach of FGM is not only of a formal-legal nature. A fact of a more cultural nature is that in the event of a report of a FGM already committed, relatively few man-hours are invested in investigating possible other cases and more evidence.'

Note 38. Unlike the Dutch regime, these interest groups have far-reaching procedural authorities. They may inspect documents or make requests, e.g. have someone summoned as an expert; Nijboer, J. F., et al. (2010), at 97.

Note 39. Including the leading women's rights organisations 'Ligue pour le Droit des Femmes and the Groupe pour l'Abolition des Mutilations Génitales Féminines' (GAMS).

Note 40. Guiné, A., \& Moreno Fuentes, F. J. (2007), at 502; Kool, R. S. B., et al. (2005), Chapter 6; Nijboer, J. F., et al. (2010), at $94 \mathrm{ff}$.

Note 41. Nijboer, J. F., et al. (2010), at Appendix 5.

Note 42. In fact the feminist quarter has criticised such defences, as the women in question were thus portrayed as victims of their own culture without a will of their own; among others Winter 1994, p. 948.

Note 43. Kool, R. S. B., et al. (2005). Chapter 6, para. 6; Nijboer, J. F., et al. (2010), at $141 \mathrm{ff}$.

Note 44. In response to the (seemingly) successful French approach, the Dutch House of Representatives insisted on a comparative law study in order to examine whether the Netherlands were to follow the French example. The Secretary of State also paid a working visit. For the research report: Nijboer, J. F., et al. (2010). 
Note 45. In addition, they point out that French criminal law lacks the minimum evidence requirement; the 'conviction intime' suffices; Nijboer, J. F., et al. (2010), at 164. Putting in perspective the French success as well: Kool, R. S. B., et al. (2005), Chapter 10, para. 4.

Note 46. Nijboer, J. F., et al. (2010), at $161 \mathrm{ff}$.

Note 47. In comparison we refer to the resistance encountered in the Netherlands in this respect. A proposal for the introduction thereof by the then Member of Parliament Hirsi Ali resulted in strong resistance; from the privacy point of view objections were raised; Raad voor de Volksgezondheid. (2005), at 18-11; Kool, R. S. B., et al. (2005), at Chapter 5. In fact, these examinations in France appear to have a counter-effect: circumcision is postponed until the moment at which the child is not subject to the obligatory medical examination any more.

Note 48. Guiné, A., \& Moreno Fuentes, F. J. (2007), at 493.

Note 49. Guiné, A., \& Moreno Fuentes, F. J. (2007), at 501; Nijboer, J. F., et al. (2010), at 110.

Note 50. Assemblée Nationale. (24 June 2010). doc. no. 2658, at 3; Assemblée Nationale. (13 November 2012). doc. no. 368.

Note 51. Articles 113-6 and 113-7 Code Penal. This legislative amendment came into effect with retroactive force; Nijboer, J. F., et al. (2010), at 81.

Note 52. This view has been formulated prominently in the influential Parekh-rapport. This report discusses the development of the United Kingdom as a multicultural nation; Runnymede Trust. (2000). Also: Guiné, A., \& Moreno Fuentes, F. J. (2007), at 486.

Note 53. The quote stems from Fortier, A. M. (2000) Retrieved from www.lancs.ac.uk/fass/sociology/papers/fortier-multicultuturalism.pdf.

Note 54. Fortier, A. M. (2000), at 2.

Note 55. Young, J. (1999), at 90. Young puts the idea that the English views are a sign of racism into perspective; he interprets the hostile tone towards newcomers as stemming from a certain conservatism that is driven by the desire to maintain 'the English community'.

Note 56. Mirza, H. S. (2012). In the same compilation: Sales, R. (2012).

Note 57. The words were taken from a speech by the former Labour Minister Roy Jenkins, delivered in 1966. Poulter considers this speech to be the turning point in English politics; Poulter, S. (1986), at 592.

Note 58. Mirza speaks of a 'faith based approach multi faithism' and a 'hard won' political turning point; Mirza, H. S. (2012), at. 121-123. Also: Fortier, A. M. (2005); Poulter, S. (1986), at 59; WRR. (2006), at. par. 4.3.1.

Note 59. An illustration hereof is the involvement and method of the UK All -Party Parliamentary Group on Population, Development and Reproductive Health (APPG). The APPG, consisting of a group of parliamentarians aiming for a dialogue between Parliament, the people in the field and ethnical minorities in recent years has actively and successfully called attention to the issue of female genital mutilation by organising hearings and Parliamentary questions; APPG. (2000). See also HM Government. (2013), at 7, 19 and 31. Retrieved from www.homeoffice.gov.uk/publications. See also: Guiné, A., \& Moreno Fuentes, F. J. (2007), at 491-492.

Note 60. Guiné, A., \& Moreno Fuentes, F. J. (2007), at. 487-488

Note 61. Guiné, A., \& Moreno Fuentes, F. J. (2007), at. 493. This undertone can be heard in what Mirza writes, and may also be found in opinions on the punishability of other cultural offences, e.g. of forced marriages; Mirza, H. S. (2012).

Note 62. See Fortier, who states that the approach advocated in the Parekh report and endorsed at the time by the English government comes down to a "pluralist model of managing cultural pluralism in a human rights framework'; Fortier, A. M. (2000).

Note 63. Cf. Dustin, M. (2010), at 19.

Note 64. Dorkenoo, E., et al. (2007).

Note 65. Reported in: The Independent On Sunday, Special report: Female genital mutilation unreported, ignored and unpunished. (2013, January 6). This involved a recently executed journalistic research report that caused a lot of commotion on account of its conclusion that the fight against female genital mutilation in England had failed. 
Note 66. Prohibition of Female Circumcision Act 2003, section 5: 'For the purpose of determining whether an operation is necessary for the mental health of a girl it is immaterial whether she or any other person believes that the operation is required as a matter of custom or ritual.'

Note 67. In order to promote consciousness of the punishability of female genital mutilation, a pilot was started recently with the issuance of a so-called 'health passport', especially in the relevant countries of origin. The objective is to protect English immigrant girls, who travel to relatives in their countries of origin, against genital mutilations practised there; HM Government. (2012).

Note 68. Supplementary to the Guidance, operating instructions were formulated for assistance prosecutors: CPS Female Genital Mutilation Pack. One of the instructions reads that on suspecting female genital mutilation one should contact a so-called Violence Against Women Coordinator (VAWC). Retrieved from www.cps.gov.uk/legal/d_to_g/female_genital_mutilation/

Note 69. HM Government. (2013). Also: Home Office. (2013).

Note 70. Home Office. (2011); Black, J. A. \& Debelle, G. D. (1995).

Note 71. Home Office. (2011), at 19.

Note 72. Questions were recently asked in the House of Commons in response to the observation that between November 2009 and November 201163 cases had been reported to the Metropolitan Police, whereas not once had a prosecution been instituted; www.bbc.co.uk, Pears call for Action on Female Genital Mutilation. This resulted in a call for action to the English government to tighten its approach of female genital mutilation; www.parliament.uk/lords.hansard, column 1282 (House of Lords) and a motion of the House of Commons, adopted unanimously; see www.parliament.uk/edm/2010-12/1219. In addition, both the adoption of the Draft Resolution Aimed at Intensifying Global Effort to Eliminate Female Genital Mutilation by the United Nations (United Nations 20 December 2012, GA/SHC/4061, Third Committee, 46), and the publication of the aforesaid critical journalist research report play a role (The Independent on Sunday, 6 January 2013).

Note 73. In 1993 two doctors were judged guilty of 'serious professional misconduct' by a medical disciplinary tribunal.One doctor had genitally mutilated a woman, although he was aware of its punishability; the other had offered to perform the operation. The first doctor was deleted from the medical register.

Note 74. Incidentally, Parliamentary questions had been asked before, but specific attention for female genital mutilation started only as of 1993; Aanhangsel Kamerstukken [Appendix Parliamentary Papers] II 1982/83, no. 964.

Note 75. According to the WRR this earlier 'open' attitude is to be put into perspective. They point out that although Dutch culture was receptive to external influences for a long time, these were 'often made invisible by strongly nationalising them. A kind of disappearing trick took place, as it were'; WRR. (2006), at 81. Comp. Koopmans, R., et. al. (2005).

Note 76. The political debate was started around the year 2000, in particular by the leader of the Dutch Liberal Party (VVD), Frits Bolkestein. In the media as well critical reports appeared, such as the article by Paul Scheffer in the NRC of January 29 2000, in which he described the 'multicultural drama'.

Note 77. The immediate cause for this was the publication of the report 'Building bridges' (by the Blok Committee); the subject of the report was Dutch integration policy. Also: WRR. (2006), at 36 and 88-89 and Van Meeteren, M. (2005).

Note 78. The term 'thick identity' has been derived from Ghorashi; Ghorashi, H. (2006).

Note 79. According to the WRR, the Dutch identity has a somewhat 'implicit and sunk character' that permits little reflection on the normative principles at its basis; WRR. (2006), at 83. Dutch criminal law also bears the signs hereof, as 't Hart argued; 't Hart, A. C. (2000).

Note 80. Parliamentary Papers II 2003/04, 29 200, XVI, 231, p. 7.

Note 81 . Government position on female genital mutilation, Letter Ministry of Welfare, Public Health and Culture, reference GGB/HIZ/931029, March 26 1993, at1. The Dutch criminal law system as a rule contains general criminal provisions.

Note 82. Appendix Parliamentary Papers 1990/91, no. 1125, p. 2.

Note 83. See also Public Prosecution Service, Instruction investigation and prosecution child abuse, Stcrt. 2010, 19123. 
Note 84. Article 5a Dutch Penal Code; Stbl. 2006, 11 and Act of March 72013 on the extension of the possibilities for a criminal law approach to forced marriage, polygamy and female genital mutilation, Stbl. 2013, 95; effective date still to be determined.

Note 85 . This reporting code became effective on July 1, 2013, Stcrt. 2013, 8838.

Note 86 . It may be noted that the Instruction investigation and prosecution child abuse prescribes prosecution in case there is sufficient proof; Stcrt. 2010, 19123, p. 6.

Note 87. Parliamentary Papers II 2011/12, 28 345, no. 117.

Note 88. It is reported that at least one cutter was active on Dutch soil in 2012. Source: oral information project coordinator 'Nieuwegein halts female genital mutilation' December 2012.

Note 89. Rb [District Court] Haarlem 11 September 2009, LJN BJ7447, on appeal: Hof [Court of Appeal] Amsterdam 23 December 2012, LJN BO8531. In both instances (partial) acquittals were pronounced. It was an established fact that the five-year old girl had been circumcised, but there was no conclusive evidence that the suspect (the father) had performed it. In January 2013 a second case was submitted to the Rechtbank [District Court] Dordrecht, but judgment was deferred. Both normal child abuse and circumcision are suspected. It is expected that the latter will not be included in the final indictment.

Note 90. The right-wing liberal Freedom Party (PVV) particularly insists on this. As of 2008 six motions were submitted in the name of the PVV, aimed at intensifying the combat of female genital mutilation. The proposals included increasing the maximum penalty, but also halting the asylum procedure and/or withdrawing one's residence permit in case of suspected female genital mutilation.

Note 91. Stbl. 2013, 95; this statute introduces an extension of the punishability of forced marriages and polygamy and also provides in an (a further) extension of the extraterritorial jurisdiction for these offences. At the moment of writing this article, the effective date is yet unknown.

Note 92. Cf. Van den Brink M., \& Tigchelaar, J. (2012).

Note 93. Kool, R. S. B. (2012).

\section{Copyrights}

Copyright for this article is retained by the author(s), with first publication rights granted to the journal.

This is an open-access article distributed under the terms and conditions of the Creative Commons Attribution license (http://creativecommons.org/licenses/by/3.0/). 